\title{
RBV in a context of supply chain management
}

\author{
A RBV em contexto de gestão da cadeia de suprimentos \\ Valdir Antonio Vitorino Filho ${ }^{1}$ (1), Roberto Giro Moori ${ }^{2}$ \\ ${ }^{1}$ Instituto Federal de São Paulo - IFSP, Capivari, SP, Brasil. E-mail: valdir.vitorino@gmail.com \\ ${ }^{2}$ Universidade Presbiteriana Mackenzie - UPM, Programa de Pós-graduação em Administração - PPGA, \\ São Paulo, SP, Brasil. E-mail: roberto.g.moori@gmail.com
}

How to cite: Vitorino Filho, V. A., \& Moori, R. G. (2020). RBV in a context of supply chain management. Gestão \& Produção, 27(4), e4731. https://doi.org/10.1590/0104-530X4731-20

\begin{abstract}
The aim of this study was to evaluate the supply chain management (SCM), strategic management (SM), and resource-based view (RBV) as background to business performance (BP). The study, exploratory in nature, was divided into two phases, qualitative and quantitative. In the first phase, data from ten companies were collected, later processed by content analysis. In the second phase, there was a pre-test, with subsequent data collection from 125 national companies associated with technology, processed by structural equation modeling. The results indicated that SCM favors SM and that both SCM and SM benefit RBV, therefore increasing BP. However, SM does not influence BP positively. Thus, we concluded that, due to the competition in the supply chain, focal companies have adopted strategies to integrate and coordinate the processes of their sectors, such as production, purchase, sales, and logistics to meet the goals of business performance.
\end{abstract}

Keywords: RBV; Supply chain management; Business performance.

Resumo: $O$ objetivo deste artigo foi avaliar a gestão da cadeia de suprimentos (GCS), gestão estratégica (GE) e a resource-based view (RBV) como antecedentes ao desempenho de negócios (DN). O estudo, de natureza exploratória, foi dividida em duas fases, qualitativa e quantitativa. Na primeira fase foram coletados dados de dez empresas, posteriormente tratados por análise de conteúdo; na segunda fase houve um pré-teste, com posterior coleta de dados de 125 empresas nacionais associadas à tecnologia, tratados por modelagem em equações estruturais. Os resultados indicaram que a GCS favorece a GE; tanto GCS como GE beneficiam a RBV, por sua vez aumentando o DN. Porém, a GE não influencia positivamente o DN. Assim, se conclui que por conta da competição na cadeia de suprimentos, as empresas focais adotaram estratégias de modo a integrar e coordenar os processos de seus membros como produção, compras, vendas e logística para atender às metas de desempenho de negócios.

Palavras-chave: RBV; Gestão da cadeia de suprimentos; Desempenho de negócios.

\section{Introduction}

For many companies, the supply chain management (SCM) has become a central element of strategic management (SM) in recent years, as a way to increase their competitiveness in the global market (Hult et al., 2007). The SCM offers to SM a new level of analysis and possibly a new organization and, generally, the interaction

Received Mar. 22, 2018 - Accepted July 26, 2018

Financial support: None.

This is an Open Access article distributed under the terms of the Creative Commons Attribution License, which permits unrestricted use, distribution, and reproduction in any medium, provided the original work is properly cited. 
between these areas broadens a company's ability to achieve its goals (Ketchen \& Giunipero, 2004). Supply chain (SC) strategies provide greater agility to operations and improve efficiency when working integrated with information systems (Paulraj \& Chen, 2007).

As for the resource-based view (RBV) (Barney, 1991), it assists companies to develop agility, adaptability, and alignment regarding SCM (Dubey et al., 2018). The resources of heterogeneity, allocation, independence, use, and imitability stand out in the creation of separate capabilities to increase business performance (Walker et al., 2015).

To improve performance and survive in an increasingly competitive market, companies have directed efforts to establish relationships collaborating with partners upstream and downstream, providing benefits throughout the SC (Xu et al., 2014). In this scenario, the RBV uses its resources, consisting of all tangible and intangible assets, human and non-human, to add value to its products and services (Wernerfelt, 1984; Barney, 1991).

From a different point of view, Frohlich \& Westbrook (2001), Flynn et al. (2010), and Cao \& Zhang (2011) highlight the relevance of integration and collaboration in intra and inter-organizational activities on SCM to increase BP. To this end, companies seek to operate together - integrating with their suppliers to ensure the quality of the product, and with their clients to follow changes in demand.

In this line of research, stands out a gap in studies developed from the premise of collaboration between the different links in the SC to achieve better business performance, involving the formation of strategic partnerships for resource investments, and sharing of information, rewards, and responsibilities (Mentzer et al., 2001; Paulraj \& Chen, 2007).

Based on the presented issues, this study aims to analyze if the theoretical constructs of SM, SCM, and RBV positively influence business performance (BP), from a model of SCM that incorporates the other two constructs as background to BP. To this end, we opted for an exploratory research with qualitative and quantitative phases, respectively, investigating 125 companies associated to the Brazilian technology poles of Belo Horizonte (MG), Blumenau (SC), Campinas (SP), Recife (PE), Rio de Janeiro (RJ), and São José dos Campos (SP). Our goal was to answer the following problem-question: what is the role of SCM, SM, and RBV as background to business performance in the companies from the main national technology poles?

As factors that justify the relevance of this research, we highlight: a) the prominent growth in the area of Research and Development (R\&D) in Brazil (FecomercioSP, 2016); b) the growing initiatives to create technology poles in the five Brazilian regions (Brasil, 2014); c) the action of these poles on regional development, generating synergy for the transfer of knowledge and technology between different agents, and on the development of innovative products and processes (Oliveira, 2011); and d) the search for planning, management, and control of the material flow by SCM, since the supplier of raw materials to the final consumer, to aggregate, in an efficient and agile way, value to all members of the chain, thus improving BP (Pires, 2016).

Characterized the research object, the guiding question, and its goal, the following sections shall present the development of the theoretical framework, with definition of the constructs and theoretical-empirical model; the methodological procedures adopted; data analysis and discussion of the results; and, finally, the conclusions and suggestions for further studies. 


\section{Theoretical reference and hypotheses}

Regarding the investigations on the performance in supply chains, we cite a study by Greene $t$ al. (2008), which investigated the influence of logistics processes in the SC strategy, resulting in a better performance in a global context, as well as a study by Sacomano \& Pires (2012), which reported how performance measures upstream from the chain are strongly related to aspects such as quality, production, and quality of deliveries, while measures downstream from the chain have strategic and marketing character.

The constructs definitions and the hypothesis for the statistical test of the developed model are detailed below.

\subsection{Constructs definition}

The model incorporated the following constructs: a) supply chain management; b) strategic management; c) resource-based view; and d) business performance.

SCM aims to align the key companies to achieve a tangible and intangible goods flow to effectively meet clients' needs and desires, offering returns for the entire chain (Harrison et al., 2007). Decision making in SCM must take into account the SM, development of products, clients, production, supply, and logistics (Sukati et al., 2012).

$\mathrm{SM}$ involves decisions that shape the RBV of companies in the long term, in function of SC and their global strategy, through on-going reconciliation and adjustments in accordance with the market's needs and the available resources (Melnyk et al., 2009).

These resources, as designed in RBV, are divided into: a) physical, such as equipment, production scale, and location (Barney, 1991; Ghemawat \& Del Sol, 1998); b) human, such as training, skills, tacit knowledge, managerial style, social capital, incentives, and entrepreneurial thinking (Barney, 1991; Castanias \& Helfat, 2001; Griffith et al., 2006; Fink \& Neumann, 2009); c) organizational, such as management of information technologies, marketing, quality, processes, flexibility, organizational culture, and planning (Barney, 1991; Maes et al., 2005; Griffith et al., 2006; Benitez-Amado et al., 2010); d) technological, such as control and coordination systems, patents domain, innovations, and investments in technology (Grant, 1991; Branzei \& Thornhill, 2006; Fink \& Neumann, 2009); e) financial, such as capital, budget, and types of credit (Grant, 1991; Maes et al., 2005); and f) reputational, such as branding, relationship with clients, and image (Grant, 1991; Ghemawat \& Del Sol, 1998; Castanias \& Helfat, 2001).

Finally, BP reflects the volume of sales, the turnover of a company, and the return in investment and profitability compared to the competition (Green et al., 2008).

\subsection{Formulated hypotheses}

For Pires (2016), SCM deals with the holistic integration of business processes, with the basic goal of maximizing synergies throughout the production chain to more effectively meet the needs of the final consumer. Thus, strategic management in supply chains merges with economic science, as it seeks a balance among the variables that, in some way, affect the supply and demand of goods and services (Harrison \& Van Hoek, 2008); it also seeks the profitability of the business, at the same time establishing measures to condition customer satisfaction and needs (Gattorna, 2006).

To this end, SCM is not synonymous with logistics; it does not only mean to conduct the process of inventory management, isolated partnerships with suppliers, much less 
does it refer only to distribution management and purchases, and it is not solely a computational system (Lummus \& Vokurka, 1999).

As to the integrated strategic vision, Lambert et al. (1998) mention that SCM tends to failure if each company of the chain focuses only on its own results rather than return its efforts to the integration of goals and activities with those of the partner organizations. Ideally, the main objective should be SC, to reach the individuals and increase business performance. Thus, our first hypothesis proposes:

$H_{1}$ : SCM associates positively with SM.

For a SCM to be viable in the long term, it is necessary to analyze social, environmental, and economic factors (Shibin et al., 2017). To this end, the RBV theory explains the relationship between SC strategic resources and its ability to obtain a competitive advantage (Hitt et al., 2016).

RBV has received attention among the studies in operations management and SCM (Hunt \& Davis, 2012; Gligor \& Holcomb, 2014), for proposing that efforts in SC operations based on sustainability can provide competitive advantage (Touboulic \& Walker, 2015) - with it being considered one of the best conceptual bases in the chain performance (Nishant et al., 2016). Based on this theoretical justification, we present the second hypothesis, in which:

$\mathrm{H}_{2}$ : SCM associates positively with RBV.

For Gunasekaran et al. (2004), SCM has been an important component to the business strategy and contributes to increase productivity and profitability. Since the literature on strategies and technologies for SCM is extensive, performance measures have received academic and managerial attention. These measures assume two main approaches: operational, based on the four traditional competitive priorities (cost, quality, flexibility, and quality of deliveries) (Skinner, 1969; Ferdows \& De Meyer, 1990; Hill, 1994); and financial, measured by indicators such as market growth, investment return, sales growth, and profit margin on sales (Kaplan \& Norton, 1992; Li et al., 2006). Substantiated in these academic and empirical evidence, the third hypothesis assumes that:

$H_{3}$ : SCM associates positively with BP.

From the perspective of SCM, RBV indicates that better performance can be achieved by unique skills based on SC sustainability, reflecting a classical vision regarding business performance and power. SCM integrates with the strategic management level, and the RBV perspective demonstrates how this evolution adapts to the general goals for the company's performance (Touboulic \& Walker, 2015).

Miemczyk et al. (2016) argue the RBV can explain the importance of new resources in technology, knowledge, and relationships, emphasizing the role of SCM to constantly address changes in the business environment to renew its strategic resources and keep is BP.

The integration of SCM processes is an essential issue so that companies participating in the chain can best manage their resources and produce concise information to improve their own efficiency and productivity, as well as of SC as a whole, thus improving clients' satisfaction and, consequently, the company's performance (Budiarto et al., 2017). Thus, our fourth hypothesis shows that:

$\mathrm{H}_{4}$ : SM associates positively with RBV.

For Flynn et al. (2010), an effective SM derives from strategic collaboration between producers and suppliers, with shared management of intra and inter-organizational processes to achieve effective flows in products, services, information, capital, and 
decisions, thus providing more added value to clients. In this sense, Li et al. (2012) concluded that, for an effective strategic management in SC, the evaluation of key suppliers and the determination of strategic objectives together with suppliers are determining factors for BP. Furthermore, Youn et al. (2013) point out that sharing information in a strategic level is preceded by mutual trust, organizational compatibility, and senior management support. Based on these theoretical propositions and empirical evidence, the fifth formulated hypothesis states that:

$H_{5}$ : SM associates positively with BP.

Studies by Dierickx \& Cool (1989), Teece et al. (1997), and Dosi et al. (2000), shows that a RBV consists of all assets, abilities, competences, organizational processes, attributes, information, knowledge, and all that is controlled by the company, elements that enable the design and implementation of strategies to increase the efficiency and effectiveness of BP. For this superior performance to be achieved by RBV and, consequently, to create a competitive advantage, the resources must be valuable, rare, have high imitation cost or be inimitable and irreplaceable (Barney, 1991).

Of the six categories of resources mentioned before, the organizational and human are interconnected, which may become a strategic artifice, as they could improve the use conditions of the others (physical, technological, financial, and reputational) by promoting synergy and greater gains in the companies' BP and of SC (Carvalho, et al., 2014).

RBV become a relevant management theory, in which companies analyze their resources and improve their performance. Recent research also investigated models that explain the relationship between RBV and BP - for example, in the applications of information technology and its infrastructure (Sook-Ling et al., 2015), in marketing and sports management (Jensen et al., 2016), in operations management (Bromiley \& Rau, 2016), and in the outsourcing of engineering services and product development (Pereira et al., 2017) -, corroborating with the proposed positive impact. From these foundations, the sixth developed hypothesis states that:

$H_{6}$ : RBV associates positively with BP.

To operationalize the proposed problem and objective, based on the research hypotheses presented, we developed the theoretical-empirical model shown in Figure 1.

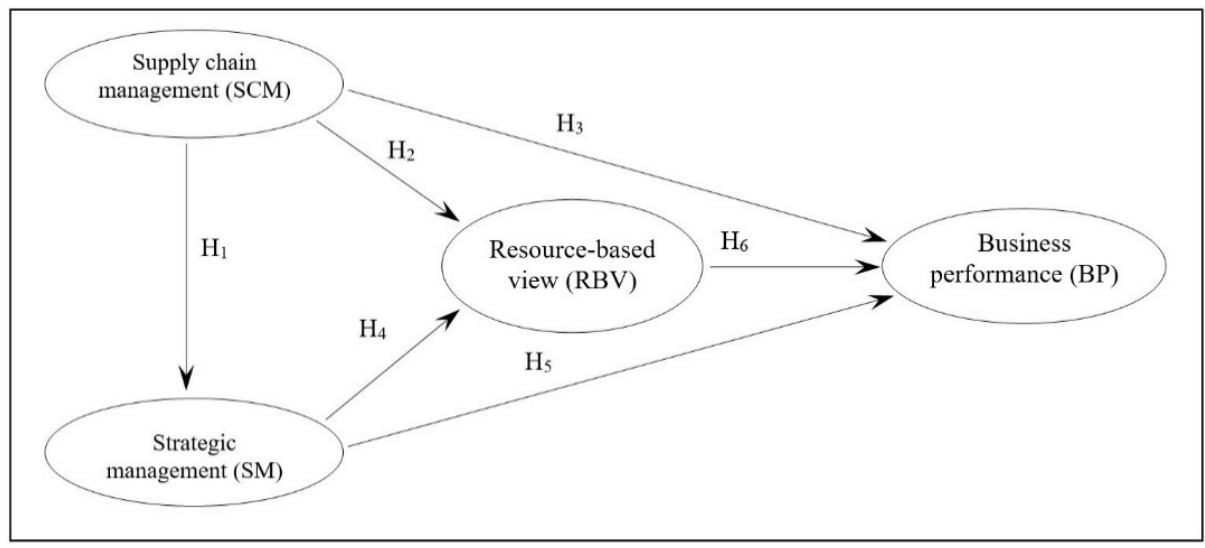

Figure 1. Theoretical-empirical model. Source: Prepared by the authors (2017). 


\section{Methodological procedures}

This section introduces the adopted methodological procedures: a) nature and typology; b) data collection instrument; c) research subject; d) processing of the collected data; and e) study and method limitations.

\subsection{Nature and typology, data collection instrument, and research subject}

This exploratory study was divided into two phases: the first, qualitative, whose goal was to promote a better understanding of the companies associated with the Brazilian technology poles, and confirm the measures and scales developed for each construct of the theoretical model.

In the first semester of 2016, ten managers from the companies associated with the Brazilian technology poles were interviewed until saturation of answers, as recommended by Lakatos \& Marconi (2017). The primary data collection occurred from a semi-structured script divided into two parts: the first, composed by data concerning the company and the respondent, and the second, consisting of five open questions, so that respondents could express their general opinions and attitudes, and whose responses were recorded on audio for later analysis (Appendix A).

The aim of this initial phase was to identify the main variables exposed in the conceptual model from the perspective of SC managers. On the other hand, the second phase's, quantitative, main contribution was the evaluation of the SCM model incorporated by SM and RBV as predecessors of performance.

Due to the number of measures per constructs, the preliminary questionnaire was submitted to a pre-test with ten companies in the first semester of 2017. After correcting it and abiding to the suggestions made in the pre-test phase, the definitive questionnaire for the second phase was prepared in three blocks, composed by: the first, a short presentation of the questionnaire; the second, characterization of the respondents and companies; and the third, measures of the research constructs (SCM, with nine measures; SM, with five; RBV, with five; and BP, with seven, totaling 26 measures). The respondents evaluated only one statement at a time, according to the degree of agreement, in six alternatives ranging from strongly disagree $(S D=1)$ to completely agree $(C A=6)$, according to which best represented their views (Appendix B).

The sample for this phase was composed of 40 companies from Campinas (SP), 51 from Belo Horizonte (MG), ten from Blumenau (SC), ten from Recife (PE), seven from Rio de Janeiro (RJ), and seven from São José dos Campos (SP) - a total of 125 companies, according to Table 1.

Table 1. Research universe and sampling.

\begin{tabular}{lcccc}
\multicolumn{1}{c}{ City/State } & N. ${ }^{*}$ Associated Companies & $\mathbf{\%}^{* *}$ & Sample & \%** $^{*}$ \\
\hline Campinas/SP & 318 & 31.09 & 40 & 32.00 \\
\hline Belo Horizonte/MG & 386 & 37.73 & 51 & 40.80 \\
\hline Blumenau/SC & 74 & 7.23 & 10 & 8.00 \\
\hline Recife/PE & 183 & 17.89 & 10 & 8.00 \\
\hline Rio de Janeiro/RJ & 24 & 2.35 & 7 & 5.60 \\
\hline São José dos Campos/SP & 38 & 3.71 & 7 & 5.60 \\
\hline
\end{tabular}

Observation: ${ }^{*}$ N. = number; ${ }^{* *} \%=$ percentage. Source: Research data (2017). 


\subsection{Data treatment}

In the qualitative phase, data from the semi-structured interviews with managers were treated by the method of content analysis (Bardin, 2011), a technique that contributed to adjust the statements of quantitative research. We tabulated the data via Microsoft Excel ${ }^{\circledR}$ and treated them with the software SPSS ${ }^{\circledR}$ (Statistical Package for Social Sciences) version 21.0 for descriptive and multivariate techniques (Hair et al., 2009). The SmartPLS ${ }^{\circledR}$ software version 2.0 was used for the structural equation modeling (Structural Equations Modeling, SEM) (Ringle et al., 2015).

The use of structural equation modeling enables the measuring, at the same time, of a set of multiple distinct and interrelated equations (Hair et al., 2009). Ringle et al. (2015), on the other hand, state that structural equation modeling (SEM) became a near-default in research in the area of administration, when it comes to analyzing cause-and-effect relations among latent constructs. SEM is based on factor analysis, so that the structural equation models are characterized by four properties, as exposed by Hair et al. (2009): a) assess the multiple and interrelated dependency relationships;

b) have the ability to demonstrate concepts which were not identified in the relations;

c) enable the correction of the estimation process regarding its measurement errors;

d) determine a model to clarify the entire set of relationships.

To analyze of the data obtained in the research, we used structural equation modeling by Partial Least Squares (SEMPLS). SEMPLS is called by Zwicker et al. (2008, p. 2) as soft modeling,

[...] for not having assumptions about the distribution of the variables, and thus having no need for transformation of the indicators, at least to decrease its asymmetry [...], being that the necessary sample size can be smaller than other confirmatory factor analysis tools. SEMPLS software are available via Internet, having as main features their speed and ease of learning compared to other confirmatory factor analysis software (Zwicker et al., 2008).

\subsection{Study and research method limitations}

The delimitation of this research took place, according to Lakatos \& Marconi (2017), by the following factors: a) object of study, which sought to fill a gap of methodological knowledge of the existing studies on the relationship between SCM, SM, RBV, and SC; b) design, with cross-sectional data collection carried out once; and c) scope, by collecting the data in six technology poles in three Brazilian regions.

The limitations of the qualitative method, according to Yin (2014), were: a) each observation was regarded as unique, i.e., dependent on the object, investigator, and participant; b) the reduction of the understanding of the other and of reality to an introspective bias (familiarity/strangeness); and c) the lack of rigorous procedures to correlate the findings and of precise rules on the techniques employed, typical of qualitative studies.

The limitations of the quantitative research method, according to Vergara (2015), occurred: a) due to sample size, with 125 respondents; and b) due to the data collection, carried out by accessibility. 


\section{Data analysis}

In this section, we present the data analysis and discussion of the results, according to: a) the profile of respondents and companies; b) validation of the constructs measures and scales; and c) validation of the structural model.

\subsection{Profile of respondents and companies}

The following data refer to the profile of respondents and of the companies investigated in the quantitative phase.

a) concerning the respondents: $63.4 \%$ were managers or directors of the companies; $34.1 \%$ worked in the area of information technology (IT), $23.6 \%$ in sales and $16.3 \%$ on purchases and supplies; $59 \%$ had a higher education degree and $41 \%$, graduate studies; $32.2 \%$ had a degree in IT and $38.7 \%$ in administration. Regarding the time in the job, $31.5 \%$ of the respondents had over five years; while $32 \%$ had been working on the company for over five years;

b) concerning the companies: $66.9 \%$ were from the IT area; $31.1 \%$ were from Campinas (SP), $37.7 \%$ from Belo Horizonte (MG), 7.2\% from Blumenau (SC), $17.9 \%$ from Recife (PE), 2.4\% from Rio de Janeiro (RJ), and 3.7\% from São José dos Campos (SP); $86.4 \%$ had up to 99 employees; and $91.2 \%$ had a turnover of $\mathrm{R} \$ 90$ million or less in 2016.

We observed that the respondents worked in areas of influence on the SCM and were able to assess the central themes of the research. The results were consistent with the profile of the companies of the studied technology poles.

\subsection{Validation of the constructs measures and scales}

To validate the measures and scales of the model constructs, we used confirmatory factor analysis, which allows for adjustments between the observed data and a theoretical model that specifies the hypothetical causal relationships between latent factors (non observable variables) and their indicator variables (observable) (Malhotra, 2012).

We adopted the principal component method, reducing data dimension by linear combinations of the original variables, to foresee the minimum number of variables needed to explain the maximum part of the represented variance (Hair et al., 2009).

Later, we obtained a series of correlation matrices by extracting principal components, to improve the interpretation of the constructs (Fornell \& Larcker, 1981), such as: a) eigenvalue, corresponding to how the factor can explain the variance, i.e., how much of the total variance of the data is associated to the factor. Since the data are standardized, each variable has zero average and variance equal to 1.0 (Corrar et al., 2009); b) Kaiser standardization, also known as latent root, in which factors with eigenvalues under 1.0 are less significant than the original variable (Corrar et al., 2009); and c) Varimax rotation, an orthogonal rotation method in which, for each main component, there are only a few significant weights, with all others being close to zero, thus maximizing the variance between the weights of each main component of the model (Fornell \& Larcker, 1981). 
After successive investigations by confirmatory factor analysis, we achieved a model composed by 19 variables, from a total of 26 , distributed in four constructs, as shown in Table 2.

Table 2. Load factor for each measure of the measurement model.

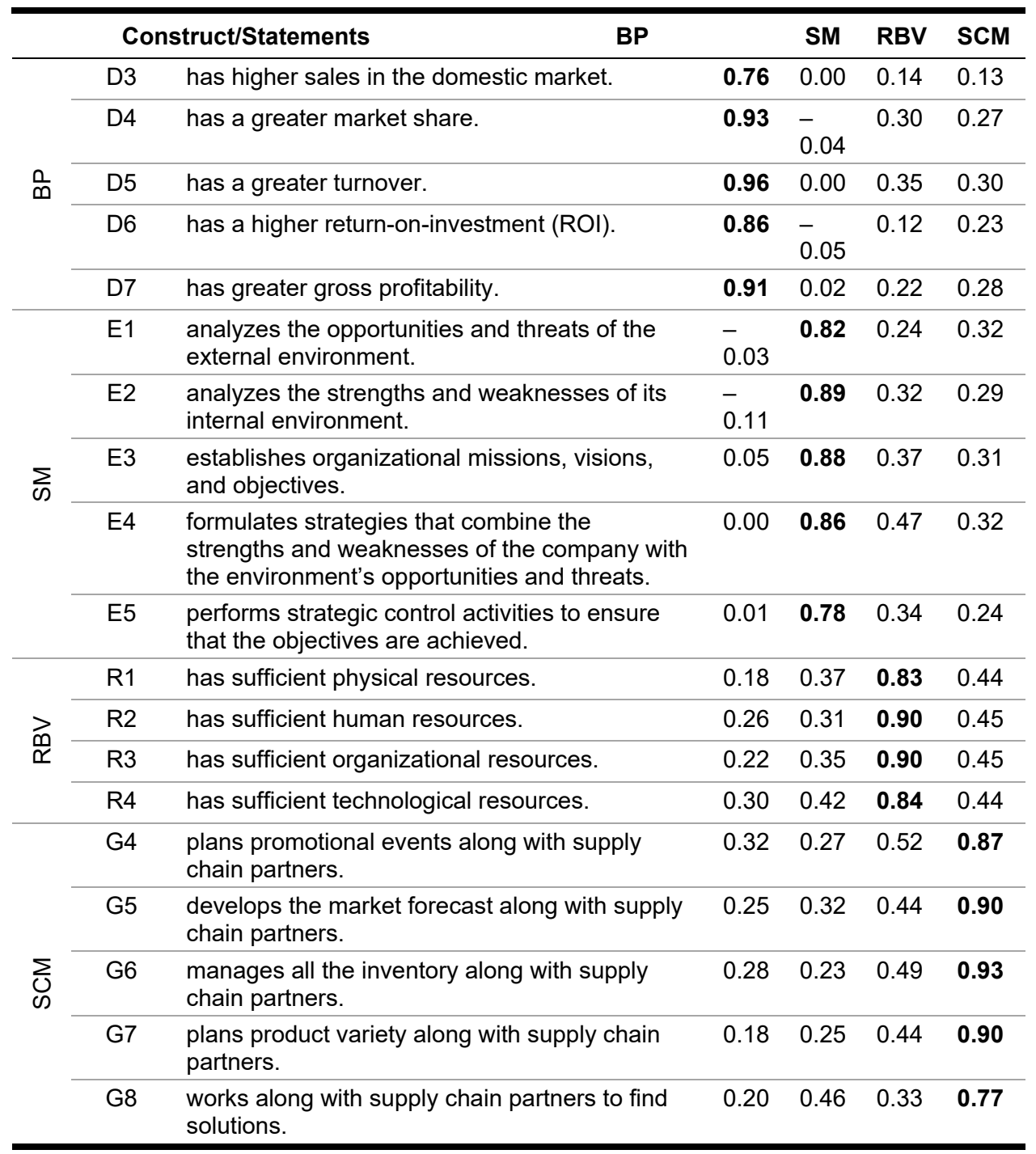

Observation: KMO (Kaiser-Meyer-Olkin Test for sampling adequacy) $=0.84$; Bartlett's sphericity test, chi-square approximation: 1948.51 ; $\mathrm{df}=171$, significance: 0.000 . All values were measured on an agreement scale ranging from strongly disagree $(S D=1)$ to completely agree $(C A=6)$. All measures were statistically significant to $(\alpha \leq 0.01)$. Source: Research data (2017).

From these results, we analyzed the measures reliability and validation. The KMO/MSA test obtained a value of 0.84 , with Bartlett's test having a significance of 0.000 , and with a $d f=171$, which reinforces, according to Hair et al. (2009), the adequacy of the data to the exploratory factor analysis, the use of Cronbach's alpha, and the presence of non-zero correlations to corroborate the validity of the theoretical model constructs. 
The eigenvalues were greater than 1.0 and the commonalities presented values above 0.5 , demonstrating that the variance proportion of the variable is shared with the common factors of the factor analysis, i.e., all factors had enough variance consistency, according to Hair et al. (2009). It should be noted that the four constructs had at least three variables, and that all presented a factor load over 0.50 , satisfying the criteria of components strength (Hair et al., 2009).

The analysis was considered adequate since it presented an explanatory variance above $60.0 \%$, and the four constructs had a Cronbach's alpha higher than 0.800 . Therefore, to the construct business performance, variables D3, D4, D5, D6, and D7 were validated, excluding D1 and D2; for strategic management, the variables E1, E2, E3, E4, and E5 were validated; for resource-based view, R1, R2, R3, and R4 were validated, excluding variable R5; and for supply chain management, G4, G5, G6, G7 and G8 were validated, excluding G1, G2, G3, and G9.

An assessment by cross charges was carried out for validation and bivariate correlation between the constructs, resulting, in all cases, in correlations of values smaller than the square root of the average variance extracted, which, according to Fornell \& Larcker (1981), is suited for the data from the analysis. In Table 3, it is possible to verify that all values of the square root, in the diagonal, were higher than the correlation between the constructs, thus ensuring that the latent variables are not grouped (Fornell \& Larcker, 1981).

Table 3. Validation and bivariate correlation between the constructs.

\begin{tabular}{ccccccc}
\hline Constructs & Average & $\begin{array}{c}\text { Standard } \\
\text { deviation }\end{array}$ & BP & SM & RBV & SCM \\
\hline BP & 3.54 & 1.11 & $\mathbf{0 . 8 8}$ & & & \\
\hline SM & 4.60 & 0.88 & -0.01 & $\mathbf{0 . 8 5}$ & & \\
\hline RBV & 4.56 & 0.89 & $0.28^{*}$ & $0.42^{\star *}$ & $\mathbf{0 . 8 7}$ & \\
\hline SCM & 4.25 & 1.13 & $0.29^{* *}$ & $0.35^{* *}$ & $0.51^{* *}$ & $\mathbf{0 . 8 8}$ \\
\hline Unidimensionality (Cronbach's alpha) $\rightarrow$ & & 0.93 & 0.90 & 0.89 & 0.92 \\
\hline Average Variance Extracted (AVE) $\rightarrow$ & & 0.78 & 0.72 & 0.75 & 0.77 \\
\hline Composite Reliability (CR) & & 0.95 & 0.93 & 0.92 & 0.94 \\
\hline
\end{tabular}

Observation: The values on the diagonal of the matrix correspond to the square root of the Average Variance Extracted (AVE). Given that these values are greater than those of the correlation, both in line and in column, there is, therefore, discriminant validity between the constructs (Fornell \& Larcker, 1981). ${ }^{* *}<0.01$ : significance level $(t>2.58)$. * $<0.05$ : significance level $(t>1.96)$. Source: Research data (2017).

The average values of the four constructs are above 3.5 , indicating that the general average level was high (Hair et al., 2009). The standard deviation for the constructs indicates that the data tend to be close to the average (Hair et al., 2009). Unidimensionality measured by Cronbach's alpha showed high levels of reliability (above 0.80), ensuring the internal consistency of the scale (Hair et al., 2009).

AVE and composite reliability (CR) presented above indexes above 0.50 and 0.70 , respectively, demonstrating that the indicators represent quality in their measurements (Fornell \& Larcker, 1981). Given the validations of measures and scales of the model, we shall go on to the validation of the structural model. 


\subsection{Validation of the structural model}

To evaluate the theoretical model proposed and the relationship between the constructs SCM, SM, RBV, and BP, we developed the structural equation modeling with the aid of the software SmartPLS 3.0, which includes a diverse set of mathematical models, computer algorithms, and statistical methods that operate together to allow the researcher to incorporate non observable concepts through indirect measures indicator variables (Ringle et al., 2015). The result is shown in Figure 2.

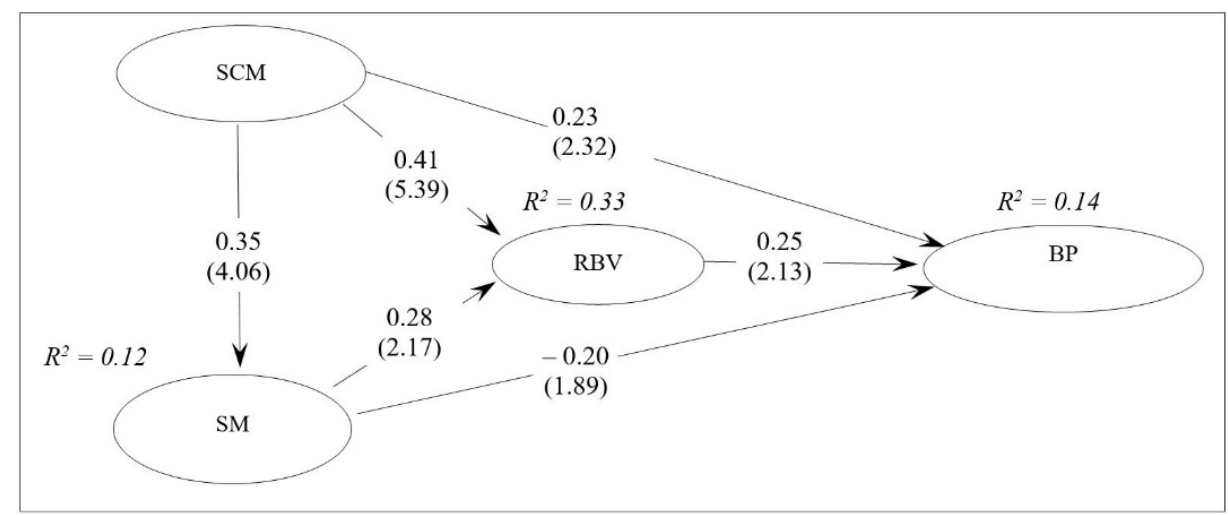

Figure 2. Theoretical-empirical model. Observation: Model estimated by the SmartPLS ${ }^{\circledR}$ software version 2.0 M3 (Ringle et al., 2015) and significances estimated by bootstrap with $\mathrm{n}=125$ and 5,000 repetitions. Source: Research data (2017).

We noted that the investigated relations obtained positive sign, confirming the favorable ratio, although in different degrees, of the latent variables, considering the limits of -1 to +1 established by Hair et al. (2009). The relationship between SCM and RBV $(0.41)$ and BP $(0.23)$ were moderate, as well as the relationship between SM and RBV (0.28), RBV and BP (0.25), and SCM and SM (0.35).

To determine the variables of adjustment quality, following the suggestion of Hair et al. (2009), we calculated the indicators of relevance of Stone-Geisser, also known as predictive validity $\left(\mathrm{Q}^{2}\right)$, and the Cohen indicators, or effect size $\left(\mathrm{f}^{2}\right)$, shown in Table 4.

Table 4. Values of the predictive validity indicators $\left(Q^{2}\right)$ and effect size $\left(f^{2}\right)$.

\begin{tabular}{ccc}
\hline Construct & CV RED $\left(\mathbf{Q}^{2}\right)^{*}$ & CV COM $\left(\mathbf{f}^{\mathbf{2}}\right)^{\star *}$ \\
\hline SCM & 0.64 & 0.64 \\
\hline RBV & 0.24 & 0.56 \\
\hline SM & 0.09 & 0.58 \\
\hline BP & 0.09 & 0.67 \\
\hline Reference values & $\mathrm{Q}^{2}>0$ & $0.02=$ small effect \\
& & $0.15=$ mean effect \\
& & $0.35=$ great effect \\
\hline
\end{tabular}

Observation: *CV RED $\left(Q^{2}\right)=$ Cross Validated Redundacy, evaluates how close the model is to what was expected of it (or the model prediction quality or adjusted model accuracy); ${ }^{* *} \mathrm{CV}$ COM $\left(\mathrm{f}^{2}\right)=$ Cross Validated Communality, evaluates how much each construct is "useful" for the adjustment of the model. Values of 0.002 , 0.15 and 0.35 are considered small, medium and large, respectively. Source: Research data (2017). 
We found that the indicator $\mathrm{Q}^{2}$ presented positive values - the model, therefore, reflects the reality, or still, has no errors. As for $\mathrm{f}^{2}$, it presented values greater than 0.30 , proving the quality of the prediction model (Hair et al., 2009).

In Table 5, we analyzed the structural coefficients and respective hypothesis testing of the theoretical-empirical model.

Table 5. Structural coefficients and hypothesis testing.

\begin{tabular}{lccccc}
\hline $\begin{array}{c}\text { Structural } \\
\text { relationship }\end{array}$ & $\begin{array}{c}\text { Structural } \\
\text { coefficient }\end{array}$ & $\begin{array}{c}\text { Standard } \\
\text { error }\end{array}$ & t value & Hypothesis & Decision \\
\hline $\mathrm{SM} \rightarrow \mathrm{BP}$ & -0.20 & 0.11 & 1.85 & $\mathrm{H}_{5}$ & $\begin{array}{c}\text { Does not } \\
\text { support }\end{array}$ \\
\hline $\mathrm{SM} \rightarrow \mathrm{RBV}$ & 0.28 & 0.10 & 2.70 & $\mathrm{H}_{4}{ }^{* *}$ & Supports \\
\hline $\mathrm{RBV} \rightarrow \mathrm{BP}$ & 0.25 & 0.12 & 2.12 & $\mathrm{H}_{6}{ }^{*}$ & Supports \\
\hline $\mathrm{SCM} \rightarrow \mathrm{BP}$ & 0.23 & 0.10 & 2.34 & $\mathrm{H}_{3}{ }^{*}$ & Supports \\
\hline $\mathrm{SCM} \rightarrow \mathrm{SM}$ & 0.35 & 0.09 & 4.03 & $\mathrm{H}_{1}{ }^{* *}$ & Supports \\
\hline $\mathrm{SCM} \rightarrow \mathrm{RBV}$ & 0.41 & 0.08 & 5.42 & $\mathrm{H}_{2}{ }^{* *}$ & Supports \\
\hline
\end{tabular}

Observation: ${ }^{* *}<0.01$ : significance level $(t>2.58)$. ${ }^{*}<0.05$ : significance level $(t>1.96)$. Source: Research data (2017).

Figure 2 and Table 4 attest that between SCM and SM, the structural coefficient was 0.35 and the $t$ value was equal to 4.03 , thus confirming $H_{1}$. Hypothesis $H_{2}$ was proven, since between SCM and RBV, the structural coefficient was 0.41 and the $t$ value was equal to 5.42. Between SCM and BP, the structural coefficient was 0.23 and the $t$ value was equal to 2.34 , thus corroborating $\mathrm{H}_{3}$. For the relationship between $\mathrm{SM}$ and RBV, the structural coefficient was 0.28 and the $t$ value was equal to 2.70 , thus proving $\mathrm{H}_{4}$. Hypothesis $\mathrm{H}_{5}$ was invalidated, since between $\mathrm{SM}$ and $\mathrm{BP}$, the structural coefficient was -0.20 and the $t$ value was equal to 1.85 , demonstrating that there is no direct relationship between the constructs. As for between RBV and BP, the structural coefficient was 0.25 and $t$ value was equal to 2.12 , thus confirming $\mathrm{H}_{6}$.

The magnitude of the direct, indirect, and total effects of the constructs of the measurement model are presented in Table 6.

Table 6. Direct, indirect, and total effects of the constructs of the measurement model.

\begin{tabular}{ccccc}
\hline Constructs & BP & SM & RBV & SCM \\
\hline BP & 0 & 0 & 0 & 0 \\
\hline SM & -0.13 & 0 & 0.28 & 0 \\
\hline RBV & 0.25 & 0 & 0 & 0 \\
\hline SCM & 0.29 & 0.35 & 0.51 & 0
\end{tabular}

Source: Research data (2017).

The constructs SCM and RBV presented positive direct effect on BP, with indexes of 0.29 and 0.25 , respectively. As for $S M$, it obtained a negative value of -0.13 , regarding $\mathrm{BP}$, reinforcing the data of Table 4, in which hypothesis $\mathrm{H}_{5}$ was not proven. The SCM construct had direct effect of 0.35 on SM, and the constructs SCM and SM obtained direct effects of 0.51 and 0.28 , respectively, on RBV. 


\section{Results discussion}

Research that addressed these three constructs together (SCM, SM, and RBV) to explain the construct business performance were scarce.

The results showed that the SCM and RBV had a significant role in explaining the BP phenomenon, influencing directly the performance of companies. The results also allowed us to conclude that the SCM of the Brazilian technology poles were in an environment that includes human resources, laboratories, and equipment with the goal of creating new processes, products, and services. Specifically, in Brazil they may be developed by the private sector or in collaboration between the public and private sectors. In their majority, they are composed of small companies, but with a few large conglomerates around these poles.

Another relevant issue to highlight is that a conglomeration of companies and institutions of education and research is not necessarily and automatically a technology pole. Other fundamental attributes are also required, such as predisposition to sharing among the involved agents, little institutional bureaucracy, and more agile and arrangements to facilitate the diffusion of the achieved technical progress.

The obtained results corroborated the investigated theory, concerning the SCM construct, with emphasis on the influence of technological variables (Lummus \& Vokurka, 1999), variety of products (Pires, 2016), establishment of partnerships at various levels and areas of SC (Lambert et al., 1998), and integrated logistic control (Green et al., 2008).

On the theoretical line of RBV, the technological poles investigated showed the importance of variables such as physical resources, with use of leading-edge equipment, infrastructure, and location of the poles (Ghemawat \& Del Sol, 1998). Human resources also stood out, highly capable and often tied to public education institutions (Fink \& Neumann, 2009).

Regarding business performance, the empirical findings point to reflections on market participation (Carvalho et al., 2014), sales amount (Green et al., 2008), increased turnover (Kaplan \& Norton, 1992), and profitability (Li et al., 2006) in the companies associated with the technology poles.

The empirical evidence on the qualitative and quantitative analyses have brought contributions to both the academic context and managerial practices, as well as aid in containing the research problem and proposed objective.

Concerning the implications of academic nature, we identified the need for a macro vision about $\mathrm{RBV}$, as well as an adaptation of the theme to the national context, more specifically in the technology poles, from the perspective of SCM and SM. Thus, it can be concluded that the research sought to fill a knowledge gap in terms of methodology, in the search for understanding the relationship among SCM, SM, RBV, and BP, relevantly adding to existing studies on technology poles.

In terms of implications for managerial practices, we can conclude that SCM and RBV are of extreme importance and source of interdependence to business performance, for both internal (such as management of materials and costs) and external issues (for example, improving the relationship with suppliers and clients), through partnerships and joint research development. 


\section{Conclusions and suggestions for further studies}

The determining factors for business performance considered in this research were: supply chain management, strategic management, and resource-based view. Such constructs were analyzed simultaneously with the Brazilian technology poles, deriving in a unpublished study in the literature of supply chain management and business performance.

The variables that composed the SM construct had no positive impact on BP; RBV had a mediator role between SCM and BP, since the direct influence of SCM on performance was lower than with the mediation of RBV. From these results, it is concluded that the variables that contributed the most to explain business performance in the national technology poles were: human and organizational resources, RBV and, in SCM, the activities of market forecast, inventory management, and planning of the variety of products developed along with members of the supply chain. We emphasize that business performance was more influenced by the variables of greater market share, higher turnover, and higher gross profitability.

Concerning the implications of this study, among the ones of theoretical nature stands out that this research sought to fill a gap of methodological knowledge of the relationship between SM, SCM and RBV on the increase of business performance, relevantly contributing to research in these areas. Regarding implications to management practices, the technology poles bring the benefits of the creation of new business undertakings, jobs generation, highly qualified labor force, and economic, social, and environmental development of a region.

The main limitations of this study were: a) regarding the sample, for not being random by definition, and for its size; b) regarding data collection, the cross-sectional cutting - it was carried out only once; and c) regarding the analysis of SCM by the vision only of the focal companies, without considering their respective suppliers, clients, and other members of the chain. However, there were many efforts to obtain accurate data, the results of the statistical tests were rigorously measured - especially those of validity and reliability of the constructs - and also, the structural equations model developed was consistent with the size of the sample.

Still, the results of this research must be viewed with reservations concerning SCM, due to sample being formed mostly by IT companies, which is an important bias, as there are peculiarities to the SC in IT companies that are very different from other areas.

Finally, we recommend three challenges for further studies: a) to develop a computational model using different rounds of simulation to assess the effect of changes in the control variables; b)to develop a scale to measure the impact of technological capabilities, thus clarifying the technology poles segment in Brazil, based on a theoretical review of the theme; and c) to reapply the study in other technology poles outside the country, even if in a longitudinal way, measuring the impacts of the variables separately in a series of studies.

\section{References}

Bardin, L. (2011). Análise de conteúdo. São Paulo: Edições 70.

Barney, J. B. (1991). Firm resources and sustained competitive advantage. Journal of Management, 17(1), 99-120. http://dx.doi.org/10.1177/014920639101700108. 
Benitez-Amado, J., Llorens-Montes, F. J., \& Perez-Arostegui, M. N. (2010). Information technology-enabled intrapreneurship culture and firm performance. Industrial Management \& Data Systems, 110(4), 550-566. http://dx.doi.org/10.1108/02635571011039025.

Branzei, O., \& Thornhill, S. (2006). From ordinary resources to extraordinary performance: environmental moderators of competitive advantage. Strategic Organization, 4(1), 11-41. http://dx.doi.org/10.1177/1476127006061029.

Brasil. Ministério da Ciência, Tecnologia, Inovações e Comunicações. (2014). Estudo de projetos de alta complexidade: indicadores de parques tecnológicos. Brasília: Anprotec. Retrieved in 2017, May 29, from http://www.anprotec.org.br/Relata/PNI_FINAL_web.pdf

Bromiley, P., \& Rau, D. (2016). Operations management and the resource-based view: another view. Journal of Operations Management, 41(1), 95-106. http://dx.doi.org/10.1016/j.jom.2015.11.003.

Budiarto, D. S., Prabowo, M. A., \& Herawan, T. (2017). An integrated information system to support supply chain management and performance in SME's. Journal of Industrial Engineering and Management, 10(2), 373-387. http://dx.doi.org/10.3926/jiem.2180.

Cao, M., \& Zhang, Q. (2011). Supply chain collaboration: impact on collaborative advantage and firm performance. Journal of Operations Management, 29(3), 163-180. http://dx.doi.org/10.1016/j.jom.2010.12.008.

Carvalho, D. M., Kedge, F. P., \& Machado, J. A. D. (2014). O uso da teoria da visão baseada em recursos em propriedades rurais: uma revisão sistemática da literatura. Revista ADM, 49(3), 506-518. http://dx.doi.org/10.5700/rausp1164.

Castanias, R. P., \& Helfat, C. E. (2001). The managerial rents model: theory and empirical analysis. Journal of Management, 27(6), 661-678. http://dx.doi.org/10.1177/014920630102700604.

Corrar, L. J., Paulo, E., \& Dias, J. M., Fo. (Eds.). (2009). Análise multivariada: para os cursos de administração, ciências contábeis e economia. São Paulo: Atlas.

Dierickx, I., \& Cool, K. (1989). Asset stock accumulation and sustainability of competitive advantage. Management Science, 35(12), 1504-1511. http://dx.doi.org/10.1287/mnsc.35.12.1504.

Dosi, G., Nelson, R., \& Winter, S. (Eds.). (2000). The nature and dynamics of organizational capabilities. Oxford: Oxford University Press.

Dubey, R., Altay, N., Gunasekaran, A., Blome, C., Papadopoulos, T., \& Childe, S. J. (2018). Supply chain agility, adaptability and alignment: empirical evidence from the Indian auto components industry. International Journal of Operations \& Production Management, 38(1), 129-148. http://dx.doi.org/10.1108/IJOPM-04-2016-0173.

FecomercioSP. (2016). Parques tecnológicos são promessas para o desenvolvimento do país. Retrieved in 2018, January 27, from http://bit.ly/2G3VKwr

Ferdows, K., \& De Meyer, A. (1990). Lasting improvements manufacturing performance: in search of a new theory. Journal of Operations Management, 9(2), 168-184. http://dx.doi.org/10.1016/0272-6963(90)90094-T.

Fink, L., \& Neumann, S. (2009). Exploring the perceived business value of the flexibility enabled by information technology infrastructure. Information \& Management, 46(2), 90-99. http://dx.doi.org/10.1016/j.im.2008.11.007.

Flynn, B. B., Huo, B., \& Zhao, X. (2010). The impact of supply chain integration on performance: a contingency and configuration approach. Journal of Operations Management, 28(1), 58-71. http://dx.doi.org/10.1016/j.jom.2009.06.001.

Fornell, C., \& Larcker, D. F. (1981). Evaluating structural equation models with unobservable variables and measurement error. JMR, Journal of Marketing Research, 18(1), 39-50. http://dx.doi.org/10.1177/002224378101800104. 
Frohlich, M. T., \& Westbrook, R. (2001). Arcs of integration: an international study of supply chain strategies. Journal of Operations Management, 19(2), 185-211. http://dx.doi.org/10.1016/S0272-6963(00)00055-3.

Gattorna, J. (2006). Living supply chains. Upper Saddle River: Prentice Hall.

Ghemawat, P., \& Del Sol, P. (1998). Commitment versus flexibility? California Management Review, 40(4), 26-42. http://dx.doi.org/10.2307/41165963.

Gligor, M. D., \& Holcomb, M. (2014). The road to supply chain agility: an RBV perspective on the role of logistics capabilities. International Journal of Logistics Management, 25(1), 160179. http://dx.doi.org/10.1108/IJLM-07-2012-0062.

Grant, R. (1991). The resource-based theory of competitive advantage: implications for strategy formulation. California Management Review, 33(3), 114-135. http://dx.doi.org/10.2307/41166664.

Green, K. W., Jr., Whitten, D., \& Inman, R. A. (2008). The impact of logistics performance on organizational performance in a supply chain context. Supply Chain Management, 13(4), 317-327. http://dx.doi.org/10.1108/13598540810882206.

Griffith, D. A., Noble, S. M., \& Chen, Q. (2006). The performance implications of entrepreneurial proclivity: a dynamic capabilities approach. Journal of Retailing, 82(1), 51-62. http://dx.doi.org/10.1016/j.jretai.2005.11.007.

Gunasekaran, A., Patel, C., \& McGaughey, R. E. (2004). A framework for supply chain performance measurement. International Journal of Production Economics, 87(3), 333-347. http://dx.doi.org/10.1016/j.jpe.2003.08.003.

Hair, J. F., Jr., Anderson, R. E., Tatham, R. L., \& Black, W. C. (2009). Multivariate data analysis with readings $(7$ th ed.). Upper Saddle River: Prentice-Hall.

Harrison, A., \& Van Hoek, R. (2008). Logistics management and strategy: competing through the supply chain (3rd ed.). Upper Saddle River: Prentice Hall.

Harrison, A., Godsell, J., Skipworth, H., \& Wong, C. Y. (2007). Developing supply chain strategy: balancing shareholder and client value: a management guide. Bedford: Crafield University Press.

Hill, T. J. (1994). Manufacturing strategy: text and cases (2nd ed.). Burr Ridge: Irwin.

Hitt, M. A., Xu, K., \& Carnes, C. M. (2016). Resource-based theory in operations management research. Journal of Operations Management, 41(1), 77-94. http://dx.doi.org/10.1016/j.jom.2015.11.002.

Hult, G. T. M., Ketchen, D. J., Jr., \& Arrfelt, M. (2007). Strategic supply chain management: improving performance through a culture of competitiveness and knowledge development. Strategic Management Journal, 28(10), 1035-1052. http://dx.doi.org/10.1002/smj.627.

Hunt, S. D., \& Davis, D. F. (2012). Grounding supply chain management in resource-advantage theory: in defense of a resource-based view of the firm. The Journal of Supply Chain Management, 48(2), 14-20. http://dx.doi.org/10.1111/j.1745-493X.2012.03266.x.

Jensen, J. A., Cobbs, J. B., \& Turner, B. A. (2016). Evaluating sponsorship through the lens of the resource-based view: the potential for sustained competitive advantage. Business Horizons, 59(2), 163-173. http://dx.doi.org/10.1016/j.bushor.2015.11.001.

Kaplan, R. S., \& Norton, D. P. (1992). The balanced scorecard: measures that drive performance. Harvard Business Review, 70(1), 71-79. PMid:10119714.

Ketchen, D. J., Jr., \& Giunipero, L. C. (2004). The intersection of strategic management and supply chain management. Industrial Marketing Management, 33(1), 51-56. http://dx.doi.org/10.1016/j.indmarman.2003.08.010.

Lakatos, E. M., \& Marconi, M. A. (2017). Fundamentos de metodologia científica (8. ed). São Paulo: Atlas. 
Lambert, D. M., Cooper, M. C., \& Pagh, J. D. (1998). Supply chain management: implementation issues and research opportunities. International Journal of Logistics Management, 9(2), 1-19. http://dx.doi.org/10.1108/09574099810805807.

Li, S., Ragu-Nathan, B., Ragu-Nathan, T. S., \& Subba Rao, S. (2006). The impact of supply chain management practices on competitive advantage and organizational performance. Omega: International Journal of Management Science, 34(2), 107-124. http://dx.doi.org/10.1016/j.omega.2004.08.002.

Li, W., Humphreys, P. K., Yeung, A. C. L., \& Cheng, T. C. E. (2012). The impact of supplier development on buyer competitive advantage: a path analytic model. International Journal of Production Economics, 135(1), 353-366. http://dx.doi.org/10.1016/j.ijpe.2011.06.019.

Lummus, R. R., \& Vokurka, R. J. (1999). Defining supply chain management: a historical perspective and practical guidelines. Industrial Management \& Data Systems, 99(1), 11-17. http://dx.doi.org/10.1108/02635579910243851.

Maes, J., Sels, L., \& Roodhooft, F. (2005). Modelling the link between management practices and financial performance: evidence from small construction companies. Small Business Economics, 25(1), 17-34. http://dx.doi.org/10.1007/s11187-005-4255-y.

Malhotra, N. K. (2012). Pesquisa de marketing: uma orientação aplicada (6. ed.). Porto Alegre: Bookman.

Melnyk, S. A., Lummus, R. R., Vokurka, R. J., Burns, L. J., \& Sandor, J. (2009). Mapping the future of supply chain management: a Delphi study. International Journal of Production Research, 47(16), 4629-4653. http://dx.doi.org/10.1080/00207540802014700.

Mentzer, J. T., DeWitt, W., Keebler, J. S., Min, S., Nix, N. W., Smith, C. D., \& Zacharia, Z. G. (2001). Defining supply chain management. Journal of Business Logistics, 22(2), 1-25. http://dx.doi.org/10.1002/j.2158-1592.2001.tb00001.x.

Miemczyk, J., Howard, M., \& Johnsen, T. E. (2016). Dynamic development and execution of closed-loop supply chains: a natural resource-based view. Supply Chain Management, 21(4), 453-469. http://dx.doi.org/10.1108/SCM-12-2014-0405.

Nishant, R., Goh, M., \& Kitchen, P. (2016). Sustainability and differentiation: understanding materiality from the context of Indian firms. Journal of Business Research, 69(5), 18921897. http://dx.doi.org/10.1016/j.jbusres.2015.10.075.

Oliveira, E., No. (2011). A importância dos parques científicos e tecnológicos no desenvo/vimento regional. Retrieved in 2018, January 27, from http://bit.ly/2ICcVUq

Paulraj, A., \& Chen, I. J. (2007). Strategic buyer-supplier relationships, information technology and external logistics integration. The Journal of Supply Chain Management, 43(2), 2-14. http://dx.doi.org/10.1111/j.1745-493X.2007.00027.x.

Pereira, R. A., Scur, G., \& Mello, F. C. (2017). Outsourcing nas atividades de desenvolvimento de novos produtos: o caso da Volkswagen do Brasil. Exacta EP, 15(2), 289-303. http://dx.doi.org/10.5585/exactaep.v15n2.6872.

Pires, S. R. I. (2016). Gestão da cadeia de suprimentos: conceitos, estratégias, práticas e casos (3. ed.). São Paulo: Atlas.

Ringle, C. M., Wende, S., \& Becker, J. M. (2015). SmartPLS 3. Bönningstedt: SmartPLS GmbH. Retrieved in 2017, August 20, from https://www.smartpls.com/

Sacomano, M., No., \& Pires, S. R. I. (2012). Medição de desempenho em cadeias de suprimentos: um estudo na indústria automobilística. Gestão \& Produção, 19(4), 733-746. http://dx.doi.org/10.1590/S0104-530X2012000400006.

Shibin, K. T., Dubey, R., Gunasekaran, A., Hazen, B., Roubaud, D., Gupta, S., \& Foropon, C. (2017). Examining sustainable supply chain management on SMEs using resource-based view and institutional theory. Annals of Operations Research, 1, 1-26. http://dx.doi.org/10.1007/s10479-017-2706-x. 
Skinner, W. (1969). Manufacturing: missing link in corporate strategy. Harvard Business Review, 47(3), 136-145. http://dx.doi.org/10.1111/j.1937-5956.1996.tb00381.x.

Sook-Ling, L., Ismail, M. A., \& Yee-Yen, Y. (2015). Information infrastructure capability and organizational competitive advantage. International Journal of Operations \& Production Management, 35(7), 1032-1055. http://dx.doi.org/10.1108/IJOPM-12-2013-0553.

Sukati, I., Hamid, A. B., Baharun, R., \& Yusoff, R. M. (2012). The study of supply chain management strategy and practices on supply chain performance. Procedia: Social and Behavioral Sciences, 40, 225-233. http://dx.doi.org/10.1016/j.sbspro.2012.03.185.

Teece, D. J., Pisano, G., \& Shuen, A. (1997). Dynamic capabilities and strategic management. Strategic Management Journal, 18(7), 509-533. http://dx.doi.org/10.1002/(SICl)10970266(199708)18:7<509::AID-SMJ882>3.0.CO;2-Z.

Touboulic, A., \& Walker, H. (2015). Theories in sustainable supply chain management: a structured literature review. International Journal of Physical Distribution \& Logistics Management, 45(1-2), 16-42. http://dx.doi.org/10.1108/IJPDLM-05-2013-0106.

Vergara, S. C. (2015). Métodos de pesquisa em administração (6. ed.). São Paulo: Atlas.

Walker, H., Chicksand, D., Radnor, Z., \& Watson, G. (2015). Theoretical perspectives in operations management: an analysis of the literature. International Journal of Operations \& Production Management, 35(8), 1182-1206. http://dx.doi.org/10.1108/IJOPM-02-20140089.

Wernerfelt, B. (1984). A resource-based view of the firm. Strategic Management Journal, 5(2), 171-180. http://dx.doi.org/10.1002/smj.4250050207.

Xu, D., Huo, B., \& Sun, L. (2014). Relationships between intra-organizational resources, supply chain integration and business performance: an extended resource-based view. Industrial Management \& Data Systems, 114(8), 1186-1206. http://dx.doi.org/10.1108/IMDS-052014-0156.

Yin, R. K. (2014). Case study research design and methods (5th ed.). Thousand Oaks: Sage.

Youn, S., Yang, M. G., Hong, P., \& Park, K. (2013). Strategic supply chain partnership, environmental supply chain management practices, and performance outcomes: an empirical study of Korean firms. Journal of Cleaner Production, 56, 121-130. http://dx.doi.org/10.1016/j.jclepro.2011.09.026.

Zwicker, R., Souza, C. A., \& Bido, D. S. (2008). Uma revisão do Modelo do Grau de Informatização de Empresas: novas propostas de estimação e modelagem usando PLS (Partial Least Squares). In Anais do XXXII Encontro da Associação dos Programas de Pós-graduação e Pesquisa em Administração. Rio de Janeiro: ANPAD. 


\section{Appendix A. Semi-structured Script - Qualitative.}

1) What makes an effective strategic management of the supply chain?

2) What are the main strategies in supply chain management used by your company?

3) What are the main factors that make your company competitive in the market?

4) When you think of the company's financial performance, what are the indicators that you consider important to measure?

5) When you think of the company's operational performance, what are the indicators that you consider important to measure?

\section{Appendix B. Close-ended questionnaire with measures of SCM, SM, RBV and BP.}

In this part of the questionnaire, divided into blocks, please note the degree of agreement with each statement presented. Consider level 1 as totally disagree and level 6 as totally agree.

\begin{tabular}{|c|c|c|c|c|c|c|c|}
\hline & \multirow{2}{*}{ My company... } & \multicolumn{6}{|c|}{ Degree of Agreement } \\
\hline & & 1 & 2 & 3 & 4 & 5 & 6 \\
\hline & \multicolumn{7}{|l|}{ Supply Chain Management } \\
\hline G1 & Selects key suppliers. & & & & & & \\
\hline G2 & Develops some kind of partnership with suppliers. & & & & & & \\
\hline G3 & $\begin{array}{l}\text { Uses information systems to exchange information with } \\
\text { suppliers (EDI, VMI, CPFR). }\end{array}$ & & & & & & \\
\hline G4 & $\begin{array}{l}\text { Plans, together with supply chain partners, promotional } \\
\text { events. }\end{array}$ & & & & & & \\
\hline G5 & $\begin{array}{l}\text { Develops, together with supply chain partners, the market } \\
\text { forecast. }\end{array}$ & & & & & & \\
\hline G6 & $\begin{array}{l}\text { Manages, together with supply chain partners, the entire } \\
\text { inventory. }\end{array}$ & & & & & & \\
\hline G7 & $\begin{array}{l}\text { Plans, together with supply chain partners, the variety of } \\
\text { products. }\end{array}$ & & & & & & \\
\hline G8 & $\begin{array}{l}\text { Works together with partners in the supply chain to find } \\
\text { solutions. }\end{array}$ & & & & & & \\
\hline \multirow[t]{2}{*}{ G9 } & $\begin{array}{l}\text { Uses information systems to exchange information with } \\
\text { customers (EDI, VMI, CPFR). }\end{array}$ & & & & & & \\
\hline & Strategic planning and management & & & & & & \\
\hline E1 & $\begin{array}{l}\text { Analyzes the opportunities and threats of the external } \\
\text { environment. }\end{array}$ & & & & & & \\
\hline E2 & $\begin{array}{l}\text { Analyzes the strengths and weaknesses of its internal } \\
\text { environment. }\end{array}$ & & & & & & \\
\hline E3 & Establishes mission, vision, and organizational goals. & & & & & & \\
\hline E4 & $\begin{array}{l}\text { Formulates strategies that combine the strengths and } \\
\text { weaknesses of the company with the opportunities and } \\
\text { threats of the environment. }\end{array}$ & & & & & & \\
\hline \multirow[t]{2}{*}{ E5 } & $\begin{array}{l}\text { Implements and carries out strategic control activities to } \\
\text { ensure that the objectives are achieved. }\end{array}$ & & & & & & \\
\hline & Resource-based view & & & & & & \\
\hline R1 & Has sufficient physical resources. & & & & & & \\
\hline
\end{tabular}


My company...

Degree of Agreement

$\begin{array}{llllll}1 & 2 & 3 & 4 & 5 & 6\end{array}$

R2 Has sufficient human resources

R3 Has sufficient organizational resources.

R4 Has sufficient technological resources

R5 Has sufficient financial resources.

\section{Financial performance}

D1 Has a good profit margin on sales.

D2 Has increased sales in the international market.

D3 Has increased sales in the domestic market.

D4 Has a larger market share.

D5 Has higher billing.

D6 Has higher return on investment (ROI).

D7 Has greater gross profitability. 